InOdia $\quad \begin{aligned} & \text { InMedia } \\ & \text { The French Journal of Media Studies }\end{aligned}$

7.1. $\mid 2018$

Visualizing Consumer Culture

\title{
Martin Parr's Signs of the Times, A Portrait of the Nation's Tastes: antidote pictures to consumerism?
}

\section{Karine Chambefort-Kay}

\section{(2) OpenEdition \\ Journals}

\section{Electronic version}

URL: http://journals.openedition.org/inmedia/1216

DOI: 10.4000/inmedia.1216

ISSN: 2259-4728

\section{Publisher}

Center for Research on the English-Speaking World (CREW)

\section{Electronic reference}

Karine Chambefort-Kay, " Martin Parr's Signs of the Times, A Portrait of the Nation's Tastes: antidote pictures to consumerism? », InMedia [Online], 7.1. | 2018, Online since 20 December 2018, connection on 10 December 2020. URL : http://journals.openedition.org/inmedia/1216 ; DOI : https://doi.org/ 10.4000/inmedia.1216

This text was automatically generated on 10 December 2020.

(C) InMedia 


\title{
Martin Parr's Signs of the Times, A Portrait of the Nation's Tastes: antidote pictures to consumerism?
}

\author{
Karine Chambefort-Kay
}

\section{Introduction}

British photographer Martin Parr has been mostly famous for his extreme close-ups, flashy colours and taste for the exuberant detail since his series Common Sense (1999). The artist is also known worldwide for his series called Small World (1995) about international tourists and the invariable globalized ways they consume heritage sites. Indeed, Martin Parr has consistently pursued an interest in how people spend their free time and money in the UK and abroad, ever since his breakthrough series about New Brighton beach-goers The Last Resort (1986). His art particularly flourished when he turned his camera to the consumer boom of the 1990s, culminating with the series Home and Abroad (1993).

2 Signs of the Times: A Portrait of the Nation's Tastes is one of Parr's early 1990s projects and perhaps the least publicized. In the long list of exhibitions of his works, it can be found only three times, ${ }^{1}$ which is much less frequent than other series. The study of the context of production and of the reception of Signs of the Times will suggest possible reasons for the marginal place of the series in Parr's work, but our main interest here will be to show that the roots of Parr's trademark images can be traced to this project and that exploring it could provide keys to much of his further takes at visualizing consumer culture.

The project Signs of the Times was commissioned to parallel a six-part BBC documentary series by film-maker Nicholas Barker about British people's tastes in home decoration, ${ }^{2}$. Eighty people were interviewed in their homes to explain how they related with whatever objects and decoration items they bought. The photographer Martin Parr collaborated to the project after each part of the film was shot. He visited thirty of the 
homes depicted in the documentary to make photos of the people in their environment and of some of their home decoration items. He then watched the rushes and transcripts of the interviews to pick quotes which could be combined with his own images. His photos were first used to advertise the series in the tube and on some bus and train stations across the country, before its broadcasting on BBC2 in January and February 1992 (Batchelor, 1992). They were also published in a book in the same year with an introductory text by Nicholas Barker. In the book, each photo was captioned with a quote from the subject in the picture. It is, to our knowledge, one of the very few occasions Martin Parr has used such a device ${ }^{3}$. Consequently, this study pays special interest to the interplay between text and image here, although it should be said that subsequent prints of the series, especially when put out for sale, did not include the quotes.

According to the title of the TV series and book, Martin Parr offered to paint a "Portrait of the Nation's Tastes", namely, to pin down the aesthetic views underlying British people's choices to buy specific decoration items. For the photographer, this involved taking pictures of homes, rooms, objects, whether banal or very intimate. Besides, as the title of the project also made clear, these home decoration options were deemed to be signs of the times, that is, related to context and trends. The following study addresses this double ambition by combining two methods: a visual, formal and aesthetic analysis of the pictures and a historicizing, cultural analysis in the late $1980 \mathrm{~s}$ early 1990s context. It will specifically discuss how Parr's pictures help us visualize consumer culture, the consumers' psyche and some of its most worrying aspects; but it will also contend that, by reaching beyond social documentary photography as it had been known so far, the photographer manages to provide an "antidote" to consumer culture-although the medicine may feel hard to swallow, as will be evidenced by a look at the critical reception of Parr's pictures.

\section{Parr's take on the 1990s national craze for home decoration}

The creation of the BBC series Signs of the Times was inspired by the recent craze for buying decoration items in a changing social context in Britain. As shown by Deborah Cohen, the surge of interest in home decoration at the turn of the 1990s was particularly visible in the proliferation of magazines about homes and gardens: from six titles in the late 80 s, the number of magazine titles soared to 35 in a decade. The best-selling title was House Beautiful, launched in 1989 and targeted at a middle-class readership living in suburban houses, which epitomized a sort of democratization of home decoration by contrast with more upmarket titles like Ideal Home or Homes and Gardens. This was related to the fact that, towards the end of the 80s, many people had become the owners of their homes after the privatization of social housing by Margaret Thatcher. As owners, people were more inclined to refurbishing their houses and to spending on decoration in the numerous stores now open. They often did everything by themselves, so that there was also a surge in DIY stores in the same period. Nicholas Barker noted this in his introduction to Parr's book:

Recent economic and social changes in Britain have led to a major upheaval of the nation's tastes. Throughout the $80 \mathrm{~s}$ a concentrated retailing marketing effort centred on the British home. During a period of apparent social mobility the British 
public required new choices to complement their changing social status, particularly as home-owners. Retailers obliged with a deluge of unfamiliar home paraphernalia, much of which was antique in design and inspired by a hotchpotch of historical fantasies: chiefly, the Country Cottage, the Farmhouse and the Stately Home. Nostalgia appears to hold a powerful grip on our national culture.

Many photos and quotes in Signs of the Times point to this new craze for interior decoration: one of them shows a lady striking a somewhat ecstatic pose on her sofa. The frame and her environment are saturated with flowery-pattern objects: wallpaper, sofa, coffee table, cushions, embroidered sofa covers. The quote "When I looked at the wallpaper and the wallpaper looked at me we instantly fell in love" adds to the notion that the lady literally has a passion for buying, perhaps for accumulating decoration items. Another picture taken in the same home, as we can tell from the wallpaper, gives a clue to the possible reasons for such decorating sprees: "I never had a home of my own before, so it was time to really splurge out." A clincher on that matter is definitely the picture from another home of a drab brownish velvet sofa with three bright cushions that seem to be desperate attempts at cheering the piece up. The caption quips: "We keep buying things thinking 'that'll look better' and it just doesn't." In such pictures, text and image point to a consuming spiral, where buyers accumulate objects only to discover that they are useless or soon out of fashion. This form of consuming craze can be pinned down in most pictures of homes and people found in Martin Parr's book.

7 Parr's project, however, should not be regarded as a truly sociological survey of the consuming habits of the British, although it seems to be documentary in kind. Indeed, many filters were used at various stages of the project, from the selection of subjects to the final edit of pictures for the book. First, here is how people and homes were chosen by Nicholas Barker:

The 80 or so people featured in the films were selected from 2,000 interviewed nationwide, [...]. They represent, in my view, a broad cross-section of contemporary taste selected according to a wide range of criteria, foremost of which were lifestage, gender, ethnicity, social class, region and personality type. No systems of quotas was introduced-some people may be cross about this-and every household chosen had to be deemed both interesting in the opinion of the production team, as well as representative of some broader issue or trend. (Parr and Barker, 1992, non paginated)

8 This extract from Barker's introduction to Parr' book certainly shows that the filmmaker, who had been trained as an anthropologist, was particularly aware of social categories, but it also clarifies that he made no claim to producing a scientific study of the British, and admitted selecting "interesting" subjects, that is to say, subjects deemed to be spectacular or entertaining enough from a TV-producer's viewpoint. In addition, the fact that participants had volunteered to join the programme upon an open call had meant that mostly people with a special interest in home decoration had been interviewed for Signs of the Times. This obviously left out of the great mass of people who did not care much about home decoration or perhaps could not afford it; it could partly account for the bias for consumption encountered in both the documentary film and photographic project.

9 Finally, Martin Parr proceeded in turn to a final selection among the 80 people featured in the film series and retained only 30 of them to be photographed. For that matter, there is no doubt that the book Signs of the Times provides quite an exacerbated view of the nation's decoration mania of the period as several filters were applied to focus on 
the most telling, if not the most spectacular cases. However, the significance of Parr's pictures lies not so much in their sociological accuracy as in the insight they provide into the driving forces of this new form of consumerism and especially into the psyche of consumers.

\section{Visualizing the consumer's psyche}

10 First, a sense of materialism and commodity fetishism is produced by the kind of pictures which compose the series: two thirds of the photos are still lives whereas one third are portraits, so that objects seems to swarm the book just as they swarm the environment of the people represented here. As the quotes come from interviews where subjects were specifically asked about their relationship to objects, it seems that material culture is particularly valued. Objects are "fetishized", to take up the Marxist view of commodities, ${ }^{4}$ in as much as they are appreciated primarily for their supposed intrinsic value-their decorative or comforting qualities in this instance-rather than for the human labour involved in their production. In fact, even when DIY houserefurbishing has probably been involved, work is hardly mentioned. Instead, emphasis is laid on buying or on the outcome of decoration efforts and expenses. One of the subjects, probably standing for the geek archetype in the series, confesses "I am just one of those people that likes to buy the latest gear", as we discover a puzzling array of objects: a Coca-Cola can with a pair of shades and headphones and a vase with black and white graphic lines, which are typical of the so-called "jazz" style of the period. They are displayed like the "household Gods" of late 1980s consumer culture ${ }^{5}$; and indeed, throughout the book, the reader gets many glimpses of mantelpieces ornate with objects arranged like fetishes. The central place given to objects in homes but also in Parr's book is a metaphor for the growing materialism of Western culture in the 80s and the way "consumption in general began to occupy such enormous amounts of time and psychic energy that it became a central fact of existence."

11 In this respect, Parr's Signs of the Times photos are typical of a change of focus in British documentary photography: "from workers to consumers" and from communal spaces to interior spaces:

In comparison with the work that originated in the 1970s, the work that began to be produced in the 1980s and early 1990s represents a significant shift, both visually and methodologically, in the representation of working class lives. Representations of communal spaces such as the street, the pub and the workplace which had dominated many visual studies of working class life up to that point, and still resonate in the popular symbolism of working class life, ceased to provide the main focus for photographic documentation. Instead, there is a greater emphasis on sites of cultural consumption and the home, including in some cases the detailed recording of the everyday lives of individual families. (...) the emergence of the notion of consumption rather than work as the locus of cultural identity became more prominent. ${ }^{7}$

12 The shift was also embodied by series produced in the same period by Nick Waplington, Richard Billingham or Anthony Haughey. Some art critics even found this to be a general trend in contemporary art in the early $1990 \mathrm{~s}^{8}{ }^{8}$ At any rate, such representations of domestic life, delving into people's individual psyches, revealed the anxieties of a new consumerist and materialistic era. 
13 Among those, was also the need to achieve a sense of individual identity. In Signs of the Times, objects are deemed to make statements about people's personalities. As revealed by the quotes in the first person, people produce their own narratives about their belongings and their character and create their own self-professed identities. The association of photos and text in Martin Parr's work testifies to this process of selfimagination and self-identification, combining visual and discursive elements. This is the case of a man who likes minimalism and whose furniture stands out as particularly sleek. His wife explains, "Henry very much needs to be different. It's important for him to live in a house that says Henry Harrisson." It is ironical that his wife should be making this comment, inevitably leading the viewers to wonder about her place in this narcissistic mise-en-scène. The man's special relationship to his environment is confirmed when the mere presence of a child's toys photographed by Martin Parr is described as bringing chaos, or perhaps, in more symbolic terms, as an encroachment upon his snug sense of self.

On the other extreme of the decoration spectrum, stand the pictures of a lady who is rather atypical in the project: she lives in what most people would define as a clutter, or, to say the least, in such an accumulation of objects that her house could hardly be considered as decorated. However, as she poses proudly among piles of boxes and baskets, she claims that it is the way she likes it, "This is my clutter. This is me. Take it. If you don't like it get out and that's your loss." On the next page, the quote " Everything's got a memory to it, and getting rid of it is like saying goodbye to the past" is associated to a close-up on an old picture of her, lying on a pile of various cosmetic products and empty packages. This sheds light onto her very intimate, organic relationship to objects and tends to make viewers cringe at what sounds like a pathological attachment to them and at the rather embarrassing voyeuristic position they are made to assume. The case of this lady was probably beyond "commodity fetishism"; but it draws attention to the fact that most subjects in the pictures had, to different degrees, "personal and emotional connections with their possessions that seemed neither healthy nor warranted."

15 Sometimes the sense of personal identification through possessions and decoration leads to competition within families: many pictures and quotes reveal a form of rivalry between man and woman in a couple, each claiming leadership in decoration choices, or interpreting some objects as the feminine or masculine touch in the house. Pictures of objects supposed to embody gender identity are powerful tools for Martin Parr to reveal sexist clichés. The text-image device is at its best-or worst-when an extreme close-up on a flowery toilet paper roll is captioned, "Sue has definitely given the bathroom the feminine touch."

16 Quite often, there is also competition between families and their neighbours, or society at large: the most ostentatiously decorated houses are ways to display one's social upward mobility or aspirations. For the picture of a particularly ornate, rococo livingroom, this is brought into light by the quote, "It's not stuff that run-of-the-mill people would have in their homes". In another instance, a man summarizes his efforts at giving a neoclassical style to his otherwise modest house with this sentence, "We've got our foot on the ladder. That's what it's all about." On a similar note, a couple, posing proudly in their recently acquired house declares, "Each to their own but I think this is going to be one of the best-if not the best-houses on the estate." Here, the composition of the photograph, with the green grass of the garden in the background, 
and the pose of the couple, with the lady sitting and the man standing to her side, are reminiscent of Georgian era portraits, particularly that of Mr. and Mrs. Andrews by Thomas Gainsborough, usually described as the epitome in British art of the $18^{\text {th }}$ century rise of the landed gentry. ${ }^{10}$ Martin Parr's picture echoes this, as it reveals the rise of individualism and social pressure in the Thatcher era.

Indeed, new tensions had appeared between personal and collective identification, or between the domestic and the public. Margaret Thatcher is remembered for her declaration that "there is no such thing as society. There are individual men and women, and there are families. And no government can do anything except through people, and people must look to themselves first. It's our duty to look after ourselves and then, also to look after our neighbour". ${ }^{11}$ Within that prospect, Britons were encouraged by successive conservative governments to make their own individual way to the top of the social ladder. Upon moving into Downing Street in 1992, the year when Signs of the Times was produced, John Major called for "a nation at ease with itself. The development of a truly classless society, with opportunities for all, from wherever they came, to do whatever they can with their own lives, by their own efforts, and with encouragement to achieve everything that they can." ${ }^{12}$ In such a frame of mind, home decoration, albeit DIY, was a means to display one's newly achieved social status or a good occasion for conspicuous consumption. We may also consider that volunteering to feature in Barker's series broadcasted by the BBC and in Parr's pictures to be exhibited in train stations only brought greater publicity and conspicuousness to one's decoration efforts and achievements. To a certain extent, this may be regarded as an anticipation of both the reality TV programmes and home improvement shows like Changing Rooms which were to flourish in the next decade.

To conclude on this exploration of the consumers' psyche through Parr's pictures, and looking at Signs of the Times as whole, it would be fair to expect social pressure to build up into distress, as most subjects in the pictures overinvest in commodities at the expense of social relations. In fact, some critics suggested that the anxieties expressed in the interviews brought excessive pathos to the TV show:

What [Barker's team] found was pathos. Self-delusion vied with fear and pomposity for the soul of Britain's home owners. Every suburban estate was full of people who thought that they had the best house in the neighbourhood. Many-like the woman who deployed paper doilies around her relentlessly contemporary light switches in pursuit of a "cottagey stately home kind of feel"-floundered in the grip of a misguided nostalgia. Caught between the promise of upward social mobility and the harsh realities of ordinariness, the British were beset by anxieties, eager to be 'a little different' but desperate, too, to fit in. 'Taste', Barker claims is all about embarrassment. ${ }^{13}$

But drawing the same conclusion about Parr's book of photographs would be overlooking a good part of the photographer's work which consists, on the contrary, in releasing some of that pressure and providing antidotes, albeit bitter, to the anxieties of consumerism.

\section{Bitter antidotes to consumerism}

Martin Parr works towards a de-dramatization of the issue, first by turning the notion of individual quest for identity on its head, thanks to the use of repetitions. It should be underlined here that Signs of the Times was produced and published as a series and that 
the set of pictures should be analysed as such. From that angle, what stands out of the book as a whole, is a lot of repetitions, echoes and networks between photos, rather than the individual tastes and trajectories of their subjects, who remain anonymous anyway. Through various motifs, viewers are made to realize that whatever the subjects' efforts at putting up a distinctive home decoration, they end up living in rather standardized environments. Just to name a few, this encompasses the taste for flowery material and carpet that many would recognize as unmistakably English or cream coloured walls. This use of recurring patterns in the book serves to debunk the narcissistic notion that people construct their own individual identities by playing up differences with others. At most, what the pictures in Signs of the Times reveal is a narcissism of small differences. Decoration expenses are only "means of calling attention to a product or to oneself as a product of self-manufacture and definition. They are attempts to use mass production to distinguish an individual commodity or a person from the mass"; $;{ }^{14}$ but Martin Parr's photos reveal that such attempts are, if not ridiculous, rather vain. They bring out the self-delusion of the subjects prone to this narcissism of small differences. In this way, Parr and other photographers "use repetition against itself, so that it ceases to provide reassurance and, in their work, becomes the source of comedy and anxiety." (Taylor, 1994, 244) This applies to objects like the Austrian valance curtains, which appear to be strangely cult objects, and contribute to a sense of comedy in the book.

21 Lightness of tone is also introduced by borrowing a few devices from the world of advertising. In fact, Martin Parr offers to visualize consumer culture by using some tools of the trade or facetiously turning its own weapons on itself. This was the case when Parr's pictures were first displayed on large hoardings on the transport network to advertise the BBC TV programme nationally. Then, the composition of the book, with thirty households decorated in various styles, emulates the categories used in the marketing of home decoration: rustic, nostalgic, Edwardian, jazz, minimalist, and so forth. Going through the book strangely feels like flipping through a catalogue on many accounts. Extreme close-ups on details and more generally, the centre stage given to objects themselves also contribute to this impression. The effect is further enhanced by the photo of the mother and daughter dressed in red which was chosen for the bookcover: the full-length, three quarter profile view evokes distance-sale catalogues if not fashion magazines.

When Signs of the Times was produced, the very use of colour was evocative of commercial photography. Indeed, colour was still rather exceptional for documentary projects, as it was considered by most practitioners and critics to belong with other types of photography. So far, colour pictures had been mostly found in magazine advertisements, amateur practices and increasingly, in artistic projects. The first were disregarded for being merely commercial and anonymous, the second, too vernacular, while the third were deemed to be too reminiscent of painting-using colour to trigger emotions-at a time when photography was still struggling to achieve recognition as an autonomous medium. All in all, colour photographs were suspected of lacking the seriousness, simplicity, and engagement traditionally associated with socially concerned black and white documentary photography in line with Lewis Hine's images of America's poor. ${ }^{15}$ Because of this, and out of a sense of subversion, Parr chose to use colour to relieve his photos from some of the pathos discussed earlier:

Well I like bright colours. I took the palette that was used for commercial photography, especially in advertising and fashion, and I applied that to the art 
world because I'm fundamentally trying to create entertainment in my photographs. The idea is to make them bright and colourful but if you want to read a more serious message in the photographs then you can do it as well. But my prime aim is to make accessible entertainment for 'the masses'. So, it's a serious message disguised as entertainment. (Parr, 2012) adverts as well. Like slogans, quotes provide keys to reading the photographs and may trigger laugh. They sometimes give an embarrassing insight into the subjects' views on family, male/female relationships, or society as a whole. In many instances, and quite ironically, the subjects of Signs of the Times sound like enthusiastic if not arrogant accomplices to the rise of individualism and consumerism in the Thatcher years or like peddlers in consumerist "propaganda." The word, used by Parr himself, refers to the alienating, dominant ideology which seems to pervade British society in a rather horizontal, indiscriminate way, as the diversity of subjects represented in Signs of the Times seems to indicate. That is why Martin Parr's exploration of their psyche and motivations, combined with distance and humour, tends to open the viewers' eyes and provide an "antidote to propaganda". ${ }^{16}$

Parr's "antidotes" have been found to be bitter by many, however. The personal style he developed was felt to be a rather unsettling mix of documentary realism-in keeping with the fly-on-the-wall style of the TV series, mostly shot in natural light-with stylistic devices borrowed from the world of advertising, as we have just shown. It is important to stress that such blurring of the lines was still unheard-of in the world of social documentary photography at the turn of the 1990s. Martin Parr and a few others like Paul Reas, Daniel Meadows or Tom Wood had already introduced the use of colour photography since the mid-80s. However, the derisive tone of the photographer was considered by some critics and colleagues to be in full breach of the codes and ethics of social documentary photography. Martin Parr was accused of condoning individualism and consumer culture through his pictures. Critics particularly attacked his choice to focus on supposedly futile subjects, thus breaking from the long tradition of documentary photography mostly dealing with working and living conditions. Stephen Dawber denounced "Parr's complicity in the chronic reduction of documentary's potential", with documentary photographs being "stripped of their vital political and utopian dimensions" in his work, which he deemed to be "privatized documentary of withdrawal". What was particularly blamed was the

distance from the intricate social relations he attempts to describe. Its refusal of the world of work colludes in undermining much sense of the political socialization of individuals. Parr's documentary amounts to an aimless, contemporary comedy of manners, complicit-more so than in the work of previous photographers- with the privatization it feigns to critique. ${ }^{17}$

Besides this Marxist criticism of Parr's projects, the cringing also came from what was felt to be Parr's lack of empathy for his subjects, or even lack of respect, especially when dealing with working-class people. These criticisms were at the heart of the controversy surrounding the election of Martin Parr as a member of the Magnum agency in 1991, the year when Signs of the Times was shot. Henri Cartier-Bresson, one the founding members of Magnum, was rather hostile to it, but the most vocal opponent was photojournalist and war reporter Philip Jones Griffiths, whose views are illuminating, despite their excessive language, for reflecting the reception of Parr's 
pictures among some documentary photographers of the previous generation and for clarifying the political stakes underlying those tensions:

$\mathrm{He}$ is an unusual photographer in the sense that he has always shunned the values that Magnum was built on. Not for him any of our concerned 'finger on the pulse of society' humanistic photography. He preached against us and was bold enough to deride us in print while his career as an 'art' photographer mushroomed....When he applied for associate membership I pointed out that our acceptance of him into Magnum would be more than simply taking on another photographer. It would be the embracing of a sworn enemy whose meteoric rise in Magnum was closely linked with the moral climate of Thatcher's rule. His penchant for kicking the victims of Tory violence cause me to describe his pictures as 'fascistic' ... Today he wants to be a member. The vote will be a declaration of who we are and a statement of how we see ourselves. His membership would not be a proclamation of diversity but the rejection of those values that have given Magnum the status it has in the world today. Please don't dismiss what I am saying as some kind of personality clash. Let me state that I have great respect for him as the dedicated enemy of everything I believe in and, I trust, what Magnum still believes in. ${ }^{18}$ Since 1947, the photos agency's humanistic ideals had been "a community of thought, a shared human quality, a curiosity about what is going on in the world, a respect for what is going on and a desire to transcribe it visually." ${ }^{19}$ For some, Martin Parr's vision was at odds with this ambition, but for others, including the photographer himself, such resentment at his depiction of consumer culture was a case of "shooting the messenger".

In hindsight, especially knowing that Martin Parr eventually became Magnum's president for three years and a half between 2014 and 2017, the coincidence between the photographer joining Magnum and the production of Signs of the Times should not be regarded so much as a symbolic turn in the agency's history as a turning point in the photographer's own career. Indeed, on several accounts does Signs of the Times epitomize the departure from conventional documentary which Parr had already embarked on in earlier projects like The Last Resort; however, shooting British people's homes and fetish objects in the context of the TV series seems to have revealed and exacerbated the photographer's interest in still-lives, whereas, so far, his projects had mostly consisted of wide shots of people in their environment. His specific interest in objects subsequently took concrete shape in his personal collection of kitsch items gathered around the world and displayed along with his photos in the Parrworld touring exhibition. In his photographs, it culminated in the use of a macro lens to produce the extreme close-ups on incongruous accessories found in his later work especially Think of England (2000).

\section{Conclusion}

Parr's book of photographs Signs of the Times has been shown to expose the absurdity and hopelessness of some consumption practices and the self-delusion they rely on, in a context of increased social pressure. Yet the series, emulating advertisements and marketing techniques on many accounts, makes a singular lot, as it turns the weapons of consumer culture against itself. This orientation of Martin Parr's work was to be confirmed in his subsequent projects, especially Common Sense, which broadened to the 
scope and showed that the traps of consumer culture had gone global. The "portrait of the nation's tastes" was now widely echoed by similar portraits of other nations. Consequently, seen through Martin Parr's work, the proliferation of objects and the supposed affluence brought by new consuming habits has looked, paradoxically, like a form of impoverishment through uniformization and futility. As Ian McEwan put it in his preface to Home and Abroad, "in Parr's world, poverty is not confined to the poor"; but regarding it as the poverty of the photographer's work would be another case of shooting the messenger or being contented with a rather limited reading of Parr's photographs.

\section{BIBLIOGRAPHY}

Batchelor, David. “My Pink Half of the Drainpipe: BBC2's Signs of the Times series". Frieze, $1^{\text {st }}$ April 1992.

Cohen, Deborah. Household Gods, The British and Their Possessions. New Haven and London: Yale University Press, 2006.

Dawber, Stephen. “Martin Parr's suburban vision”. Third Text Volume 18 Issue 3, (2004): 252-258.

Goldberg, Vicki. Light Matters: Writings on Photography. New York: Aperture, 2010.

Kimmelman, Michael. "Joys and terrors on the home front", The New York Times, September 27, 1991.

Miller, Russell. Magnum: Fifty Years at the Front Line of History: The Story of the Legendary Photo Agency. New York: Grove Press, 1997.

Newbury, Darren. "Photography and the Visualization of Working-class Lives in Britain". Visual Anthropology Review. Volume 15 Issue 1, (March 1999): 21-44.

Nicholson, Geoff. “Objects of Derision”. Modern Painters (Summer 2002): 87-91.

Parr, Martin. The Last Resort. Wallasey, Merseyside: Promenade Press, 1986.

Parr, Martin. The Cost of Living. Manchester: Cornerhouse, 1989.

Parr, Martin and Nicholas Barker. Signs of the Times: A Portrait of the Nation's Tastes. Manchester: Cornerhouse Publications, 1992.

Parr, Martin. Home and Abroad. London: Jonathan Cape, 1993.

Parr, Martin. Small World: A global photographic project 1987-1994. Stockport, Cheshire: Dewi Lewis, 1995.

Parr, Martin. Common Sense. Stockport, Cheshire: Dewi Lewis, 1999.

Parr, Martin and Quentin Bajac. Le Mélange des genres, Entretien avec Quentin Bajac. Paris: Textuel, 2010.

Parr, Martin, Marie Gautier and Aurore Fossard. "I'm the antidote to propaganda: A conversation with Martin Parr”, September 2012, La Clé des Langues (Lyon: ENS Lyon/DGESCO), http://cle.ens- 
lyon.fr/anglais/arts/photographie/i-m-the-antidote-to-propaganda-a-conversation-withmartin-parr <accessed 28 February 2018>

Taylor, John. Dream of England. Manchester: Manchester University Press, 1994.

Warner Marien, Mary. Photography, A Cultural History. London: Laurence King, 2006 [2002].

\section{ENDNOTES}

1. Janet Borden, New York (1992) and Herefordshire Photography Festival (1996), The Beetles + Huxley Gallery, London (July and August 2014).

2. Another series, From A to B, Tales of Modern Motoring, was produced in 1994 by Nicholas Barker about British people's relationship to their cars, to which Martin Parr also collaborated.

3. His work on Non-conformist churches in Hebden Bridges in the early years of his career had involved a similar text-image device based on interviews recorded in the local community by his wife Susie. (Martin Parr and Quentin Bajac, Le Mélange des genres, Entretien avec Quentin Bajac, Paris: Textuel, 2010, 10-12)

4. Karl Marx, Capital, Volume I: A Critique of Political Economy, Volume 1, Mineola, New York: Dover Publications, 2011, 83.

5. Deborah Cohen, Household Gods, The British and Their Possessions, New Haven and London: Yale University Press, 2006.

6. Vicki Goldberg, Light Matters: Writings on Photography, New York: Aperture, 2010, 137.

7. Darren Newbury, "Photography and the Visualization of Working-class Lives in Britain", Visual Anthropology Review, Volume 15 Issue 1, (March 1999), 32.

8. Michael Kimmelman, "Joys and terrors on the home front", The New York Times, September 27, 1991.

9. Geoff Nicholson, “Objects of Derision”. Modern Painters, Summer 2002, 88.

10. The parallel between Martin Parr's picture and Thomas Gainsborough's Mr And Mrs Andrews was also made in the exhibition Seduced by Art, Photography Past and Present at the National Gallery, London, 31 October 2012 to 20 January 2013.

11. Interview of Margaret Thatcher, 23 September 1987, quoted by Douglas Kay in Woman's Own, 31 October 1987, 8-10

12. John Major, speech at 10 Downing Street, 10 April 1992, http://www.johnmajor.co.uk/ page1019.html <accessed on February 28, 2018 >

13. Deborah Cohen, Household Gods, The British and Their Possessions, New Haven and London: Yale University Press, 2006, 206.

14. Vicki Goldberg, Light Matters: Writings on Photography, New York: Aperture, 2010, 139.

15. Mary Warner Marien, Photography, A Cultural History, London: Laurence King, 2006 [2002], 422; Martin Parr and Quentin Bajac, Le Mélange des genres, Entretien avec Quentin Bajac, Paris: Textuel, 2010, 35-37.

16. Parr, Martin, Marie Gautier and Aurore Fossard. "I'm the antidote to propaganda: A conversation with Martin Parr", September 2012, La Clé des Langues (Lyon: ENS Lyon/DGESCO), http://cle.ens-lyon.fr/anglais/arts/photographie/i-m-the-antidote-to-propaganda-a-

conversation-with-martin-parr <accessed 28 February 2018>

17. Stephen Dawber, “Martin Parr's suburban vision”, Third Text, Volume 18, Issue 3, 2004, 257-259.

18. Russell Miller, Magnum: Fifty Years at the Front Line of History: The Story of the Legendary Photo Agency. New York: Grove Press, 1997, 295. 
19. Henri Cartier-Bresson, quoted on Magnum website, "About page", https:// www.magnumphotos.com/about-magnum/overview/ <accessed on February 28, 2018>

\section{ABSTRACTS}

This study of Martin Parr's book Signs of the Times: A Portrait of the Nation's Tastes (1992) traces the roots of the British photographer's interest in consumption practices and of the new form of social documentary photography that has become his trademark. We show that Parr's take on the 1990s craze for home decoration pinpoints deep shifts in British society at the end of the Thatcher era, towards more individualism and materialism. The combination of images and quotes from his subjects gives an insight into the consumers' psyche, revealing forms of commodity fetishism, narcissism of small differences, and an obsession with upward social mobility. Beyond seemingly futile decoration issues, the photos address personal identification through objects and the power relations that it involves. Yet, the photographer's distant gaze and humorous use of motifs help avoid pathos and provide viewers with an "antidote to propaganda" in Parr's own words, namely, to the dominant consumerist ideology, although this has meant a controversial departure from the traditional codes of social documentary.

\section{INDEX}

Keywords: Martin Parr, British photography, Signs of the Times, documentary photography, consumer culture, materialism, home decoration 